\title{
In Search of Topical Agricultural Biofungicides: Properties of the Recombinant Antimicrobial Peptide TrxAq-AMP Obtained from Amaranthus quitensis
}

\author{
Diego Alem ${ }^{1}$, Paola Díaz-Dellavalle ${ }^{2}$, Carolina Leoni ${ }^{3}$, Salvatore G De-Simone ${ }^{4,5}$, Agustín Correa $^{6}$, Pablo Oppezzo ${ }^{6}$ and Marco Dalla Rizza ${ }^{1 *}$ \\ ${ }^{1}$ Laboratorio de Proteínas, Unidad de Biotecnología, Estación Experimental Wilson Ferreira Aldunate, Instituto Nacional de Investigación Agropecuaria (INIA Las Brujas), \\ Canelones, Uruguay \\ ${ }^{2}$ Departamento de Ciencia y Tecnología de los Alimentos, Facultad de Ingeniería y Tecnologías, Universidad Católica del Uruguay (UCU), Montevideo, Uruguay \\ ${ }^{3}$ Sección Protección Vegetal, Programa Nacional de Investigación de Producción y Sustentabilidad Ambiental, Estación Experimental Wilson Ferreira Aldunate, Instituto \\ Nacional de Investigación Agropecuaria (INIA Las Brujas), Canelones, Uruguay \\ ${ }^{4}$ Center for Technological Development in Health (CDTS)/National Institute of Science and Technology for Innovation in Neglected Diseases (INCT-IDN), FIOCRUZ, Rio \\ de Janeiro, RJ, Brazil
}

${ }^{5}$ Biochemistryof Proteins and Peptides Laboratory, Oswaldo Cruz Institute, FIOCRUZ, Rio de Janeiro, RJ, Brazil.

${ }^{6}$ Unidad de Proteínas Recombinantes - Institut Pasteur de Montevideo, Uruguay

\begin{abstract}
Synthetic pesticides have a positive impact on food production. However, there are concerns due to the outbreak of resistance along with negative side effects on human health and the environment. New active compounds and control strategies are needed for the management of phytopathogens. Antimicrobial peptides (AMPs) are evolutionarily conserved components of the innate immune response in almost all organisms that constitute an interesting source of potential molecules for use as pesticides. The naturally derived antimicrobial peptide AqAMP (Amaranthus quitensis-Antimicrobial Peptide), obtained from Amaranthus quitensis, is cysteine-rich with activity against several phytopathogens. In the present work, we report on the expression in Escherichia coli of functionally active Aq-AMP fused to thioredoxin (TrxAq-AMP). The in vitro antifungal activity of purified TrxAq-AMP was confirmed against Alternaria solani, Fusarium oxysporum f. sp. lycopersici, Pencillium digitatum and $P$. italicum, as well as the in vivo control of $P$. digitatum in oranges. We demonstrated the stability of TrxAq-AMP in a range of $\mathrm{pH}$ (from 3 to 11) and at temperatures from $0^{\circ} \mathrm{C}$ to $100^{\circ} \mathrm{C}$. Furthermore, it maintained activity after digestion with various proteases and it displayed no haemolytic activity suggesting a highly stable and safe molecule. For topical application we present AMP with no haemolytic/phytotoxic activity that is effective, stable to a wide range of temperature and $\mathrm{pH}$, and resistant to protease activity. Besides, this molecule is naturally stored in the seed, easy to extract and potentially produced through molecular farming. These findings encourage further biotechnological research on topical application of AMPs, especially in relation to molecule bioavailability.
\end{abstract}

Keywords: Antimicrobial peptides; Alternaria solani; Fusarium oxysporum f. sp. lycopersici; Penicillium sp.; Heterologous expression

Abbreviations: AMPs: antimicrobial peptides; Ac-AMP: Amaranthus caudatus-Antimicrobial Peptide; Aq-AMP: Amaranthus quitensis-antimicrobial peptide; LB: Luria Bertani; Fmoc: Fluoren-9Methyloxycarbonyl; HPLC: High Performance Liquid Chromatography; IMAC: Immobilized Metal Affinity Chromatography; IPTG: Isopropyl B-D-1-Thiogalactopyranoside; MALDI: Matrix-Associated Laser Desorption Ionization; MFC: Minimal Fungicidal Concentration; MIC: Minimal Inhibitory Concentration; PCR: Polymerase Chain Reaction; PDA: Potato Dextrose Agar; PDB: Potato Dextrose Broth; ON: Overnight; SDS-PAGE: Sodium Dodecyl Sulfate Polyacrylamide Gel Electrophoresis; Trx: Thioredoxin

\section{Introduction}

Synthetic pesticides have a significant impact on food production by reducing crop losses due to pests, disease and weeds. Yet, these positive benefits are being reconsidered in light of negative side effects. Instances of resistance along with impacts on human health and the environment are driving the search for new active compounds and control strategies for the management of plant pathogens. Searches are focused on new molecules with various properties including high specificity for target pathogens, effectiveness at low dosages and biodegradability, with a low risk for the development of resistance by the pathogen population. A highly promising group of molecules are antimicrobial peptides (AMPs), which are evolutionarily conserved components of the innate immune response in almost all organisms and constitute a potentially interesting source of molecules for use as pesticides [1-4]. Most plant AMPs are small molecules with less than 50 amino acids, a molecular weight below $10 \mathrm{kDa}$, net positive charge, amphipathic and cysteine-rich with disulfide bonds that confer high stability $[2,5]$.

Several AMPs have been reported for controlling plant pathogens [2,5-9]. Within the Amaranthaceae family, Broekaert et al. [10] described two molecules with 29 and 30 amino acids (Ac-AMP1 and Ac-AMP2) with in vitro activity against several fungi, most of them being phytopathogens (Alternaria brassicola, Ascochyta pisi, Botrytis cinerea, Colletotrichum lindemuthianum, Fusarium culmorum, Trichoderma hamatum, Verticillium dahliae) and high stability at different $\mathrm{pH}$, temperatures and protease digestion. More recently,

*Corresponding author: Marco Dalla Rizza, Laboratorio de Proteínas, Unidad de Biotecnología, Estación Experimental Wilson Ferreira Aldunate, Instituto Nacional de Investigación Agropecuaria (INIA Las Brujas), Canelones, Uruguay, Tel: +598 3677641; Fax: 598 3677609; E-mail: mdallarizza@inia.org.uy

Received June 02, 2014; Accepted June 16, 2014; Published June 24, 2014

Citation: Alem D, Díaz-Dellavalle P, Leoni C, De-Simone SG, Correa A, et al. (2014) In Search of Topical Agricultural Biofungicides: Properties of the Recombinant Antimicrobial Peptide TrxAq-AMP Obtained from Amaranthus quitensis. J Microb Biochem Technol 6: 268-273. doi:10.4172/1948-5948.1000155

Copyright: (c) 2014 Alem D, et al. This is an open-access article distributed under the terms of the Creative Commons Attribution License, which permits unrestricted use, distribution, and reproduction in any medium, provided the original author and source are credited 
Citation: Alem D, Díaz-Dellavalle P, Leoni C, De-Simone SG, Correa A, et al. (2014) In Search of Topical Agricultural Biofungicides: Properties of the Recombinant Antimicrobial Peptide TrxAq-AMP Obtained from Amaranthus quitensis. J Microb Biochem Technol 6: $268-273$. doi:10.4172/1948-5948.1000155

AMPs from, Amaranthus retroflexus and A. hypochondriacus have been reported $[11,12]$. Also, our group identified and purified two peptides from A. quitensis seeds (Aq-AMP1 and Aq-AMP2) with the same sequence as the peptides isolated from A. caudatus (Ac-AMP1 and AcAMP2, respectively) [13].

Most analyses of AMP activity have been performed in vitro. However, a laboratory setting neglects the importance of the environment on the interactions between the plant, pathogen and AMP that can affect the in vivo activity. The high production costs associated with AMPs can explain the current limitation in analysis. Advances in biotechnological procedures could overcome these constraints by heterologous production using bacteria and yeasts [1418] or transgenic plants as biofactories [5,19-22]. Improvements in production would be a breakthrough for not only research purposes, but also for the application of AMP to plant protection. Several peptides already show satisfactory efficacy against many agricultural pathogens, .with strong potential for the production of a commercial fungicide. These AMPs must meet certain requirements, .with strong potential for the production. They must be effective and easy to produce [8]. Besides their biological properties, AMPs are easily identified molecules, allowing traceability and facilitating the regulatory requirements for registration of biopesticides for agricultural use.

In the present work, our objective was to express a functional form of the naturally derived antimicrobial peptide obtained from Amaranthus quitensis seeds (Aq-AMP), fused to thioredoxin in Escherichia coli. We further demonstrated the functionality of its in vitro antifungal activity through assays against four filamentous fungi of agricultural relevance. Finally, the in vivo activity was tested against Penicillium digitatum in Valencia oranges.

\section{Materials and Methods}

\section{Materials}

Ni-NTA affinity chromatography was used for the purification of the fusion protein. The endonucleases, Taq DNA polymerase, T4 ligase and DNA encoding a His-tag and the S-Tag were from Novagen (Madison, WI, USA). The Vydac reverse-phase C18 column was from Altech Associates, Inc. (Dearfield, IL, USA) and His Trap HP columns from GE-Healthcare (Pittsburg, PA, USA). Protein molecular weight markers, imidazole, lysozyme, protease inhibitors, IPTG, sequence reagents and synthesis solvents were purchased from Sigma-Aldrich Co (St Louis, Mo, USA). Bacto tryptone and Bacto yeast extract were from Difco-Becton Dickinson Co (Franklin Lakes, NJ, USA). Fungaflor 75 PS was acquired from Janssen Pharmaceutica (Titusville, NJ, USA) while Potato Dextrose Broth (PDB) and Potato Dextrose Agar (PDA) were from Hi Media (Mumbai, India).

\section{Strains and expression vector}

The Escherichia coli strain DH5a was used for plasmid propagation of the expression clone pET 32a. The E. coli strains BL21-DE3 pLys (Novagen) and Shuffle (New England Biolabs) were used to evaluate the optimal expression conditions of the fused protein. The expression plasmid pET32a ${ }^{(+)}$(Novagen) was used to express the recombinant construct, which was fused to thioredoxin (Trx) (109 aa) at the $\mathrm{N}$-terminal extreme, followed by a $6 \mathrm{x}$ His-Tag, a thrombin cleavage site and the Aq-AMP (86 aa) protein in the C-terminal region (Trx/ His/Aq-AMP).

\section{Microorganisms}

Four fungal strains of agricultural relevance were used for the in vitro and in vivo experiments. Alternaria solani (isolated from diseased tomato leaves), Fusarium oxysporum f.sp. lycopersici (isolated from diseased tomato stems), Penicillium digitatum and P. italicum (both isolated from orange fruits), were supplied by the Plant Pathology Laboratory of the National Institute of Agricultural Research of Uruguay. All fungal strains were cultured on PDA at $24^{\circ} \mathrm{C}$ for 7 days. Spore suspensions were obtained in a sterile solution of $0.1 \%$ Tween-20 by filtration through gauze and centrifugation $(7,000 \times \mathrm{g} ; 20 \mathrm{~min})$. Stock spore suspensions were adjusted to $2 \times 10^{6}$ spores $/ \mathrm{ml}$ after counting in a cell counting chamber and stored in $20 \%$ glycerol at $-80^{\circ} \mathrm{C}$ until use.

\section{Peptide synthesis}

The peptide Pses3 (WRQRYYRYVHGYMGPKGYTR) from Sesamum indicum was synthesized by the solid-phase synthesis method in a PSS-8 Pep Synthesizer (Shimadzu, Kyoto, Japan) according to the fluoren-9-methyloxycarbonyl (Fmoc)-polyamide active ester chemistry [9]. The synthesized peptide was purified using a reversephase $\mathrm{C}_{18}$ column and the purity was confirmed by matrix-associated laser desorption ionization (MALDI) mass spectroscopy (Kratos Kompact MALDI).

\section{Cloning of the complete gene protein Aq-AMP2 in pET32a ${ }^{(+)}$}

A. quitensis seeds were collected at the National Institute of

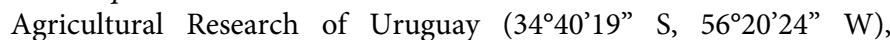
accessions numbers UB_Aq14.1 and UB_Aq14.2 deposited at the MVFA herbarium, Agronomy Faculty, Universidad de la República, Uruguay.

DNA template was extracted from seeds with specific primers (AqAMP2 ForwNco1:AAACCATGGTGAACATGAAGAGTGTTGC;AqAMP2 Rev_Xho1: TTTCTCGAGTCATGGACTACCAGCACCAG) designed on the basis of $A$. caudatus sequence information [23] and the complete protein was amplified by polymerase chain reaction (PCR) using Phusion polymerase (Finnzymes). A band with the expected molecular weight was obtained and purified by agarose gel (QIA Quick Gel Extraction kit, Qiagen). The purified PCR product and the pET32 $\mathrm{a}^{(+)}$vector were digested with the restriction enzymes NcoI and XhoI (Fermentas) according to the manufacturer's recommendations. After digestion both products were ligated with the Quick Ligation Kit (New England Biolabs) and transformed in XL1-Blue electrocompetent cells. Positive colonies were selected by digestion of purified plasmids with the restriction enzymes mentioned above and confirmed by DNA sequencing.

\section{Expression test of the construct Trx/His/Aq-AMP}

Expression assays were performed at two different temperatures $\left(16^{\circ} \mathrm{C}\right.$ and $\left.37^{\circ} \mathrm{C}\right)$ and in two different expression strains, BL21(D3)pLys and Shuffle T7 Express lysY (New England Biolabs). For the expression screening, $200 \mathrm{ml} \mathrm{LB}$ media (Luria-Bertani) complemented with 100 $\mu \mathrm{g} / \mathrm{ml}$ ampicillin were inoculated with $2 \mathrm{ml}$ overnight (ON) culture, and grown at $37^{\circ} \mathrm{C}$.

After reaching a $\mathrm{OD}_{600 \mathrm{~nm}}=0.8$, cultures were induced with $1 \mathrm{mM}$ isopropyl $\beta$-D-1-thiogalactopyranoside (IPTG), for $4 \mathrm{~h}$ at $37^{\circ} \mathrm{C}$ or $\mathrm{ON}$ at $16^{\circ} \mathrm{C}$. After induction, cells were recovered by centrifugation and resuspended in buffer $\mathrm{A}\left(50 \mathrm{mM} \mathrm{NaPO}_{4} \mathrm{pH} 8.0,0.5 \mathrm{M} \mathrm{NaCl}, 20\right.$ $\mathrm{mM}$ imidazole) with lysozyme $(1 \mathrm{mg} / \mathrm{ml})$ (Sigma Aldrich), protease inhibitors EDTA-Free (Roche Inc. USA), and frozen at $-80^{\circ} \mathrm{C}$. 
Citation: Alem D, Díaz-Dellavalle P, Leoni C, De-Simone SG, Correa A, et al. (2014) In Search of Topical Agricultural Biofungicides: Properties of the Recombinant Antimicrobial Peptide TrxAq-AMP Obtained from Amaranthus quitensis. J Microb Biochem Technol 6: $268-273$. doi:10.4172/1948-5948.1000155

Cells were thawed and sonicated with a micro-tip, performing 3 pulses of 20 seconds ( 2 seconds with a 1 second of rest) $35 \%$ amplitude and centrifuged at $17000 \times \mathrm{g}$ for $40 \mathrm{~min}$ at $4^{\circ} \mathrm{C}$. Soluble fractions were filtered on a $0.45 \mu \mathrm{M}$ membrane and injected on a column of His Trap HP $1 \mathrm{ml}$ (GE-Healthcare), previously equilibrated in buffer A. Subsequently the column was washed with 10 volumes of buffer $\mathrm{A}$ and eluted with buffer B $\left(50 \mathrm{mM} \mathrm{NaPO}_{4} \mathrm{pH} 8.0,0.5 \mathrm{M} \mathrm{NaCl}, 0.5 \mathrm{M}\right.$ imidazole). The eluted fractions were analyzed by SDS-PAGE.

\section{Tricine SDS-PAGE}

A solution of solubilizing buffer (SSB), composed of $0.5 \mathrm{M}$ Tris ( $\mathrm{pH}$ 6.8), $20 \%$ glycerol (v/v), 10\% SDS (w/v), 10\% $\beta$-mercaptoethanol $(\mathrm{v} / \mathrm{v})$, and $0.1 \%$ bromophenol blue $(\mathrm{w} / \mathrm{v})$, was freshly prepared. The solution of peptides was mixed with the fresh SSB in a ratio of 2:1, and the mixtures were incubated at $95^{\circ} \mathrm{C}$ for $5 \mathrm{~min}$. The samples were run on a discontinuous Tricine-SDS-PAGE with a $10 \%$ stacking gel and a $12 \%$ separating gel [24].

\section{Expression and characterization of the fusion protein $\operatorname{Tr} x /$ His/Aq-AMP}

Expression in 11 of LB media was carried out in the Shuffle strain. Induction was performed with $1 \mathrm{mM} \mathrm{IPTG}$ at $16^{\circ} \mathrm{C}$ ON and cells were recovered by centrifugation. The pellet was resuspended as previously described. Recombinant protein was purified by immobilized metal affinity chromatography (IMAC) using a $1 \mathrm{ml}$ HisTrap column (GE Healthcare) and eluted in a continuous gradient ( $0-100 \%$ of buffer B). Purified protein was then injected in a Superdex 10/300 (GE Healthcare) equilibrated in buffer $\mathrm{A}$ for the determination of the oligomeric state.

\section{In vitro antifungal activity assay: MIC and MFC}

The in vitro antifungal activity was determined by a quantitative micro-spectrophotometric assay [25]. Inhibition of growth was measured in 96-well microtiter plates at $595 \mathrm{~nm}$ (Multiscan FC, Thermoscientific, Shangai, China). In each well, $50 \mu$ of $50 \%$ PDB with $2 \times 10^{4}$ spores $/ \mathrm{ml}$ of fungi and $50 \mu \mathrm{l}$ of a peptide suspension at the desired concentration were mixed. After $30 \mathrm{~min}$ at $24^{\circ} \mathrm{C}$ to allow sedimentation, absorbance was measured $(\mathrm{Abs} 0)$, then the plates were incubated at $24^{\circ} \mathrm{C}$ for $48 \mathrm{~h}$ and absorbance was measured again (Abs48). Water was used as the negative control (AbsW), thioredoxin at $128.0 \mu \mathrm{M}$ was tested to rule out any effect on fungal growth, and the peptide concentrations used were $0.0,0.5,1.0,2.0,4.0,8.0,16.0$, 32.0, 64.0 and $128.0 \mu \mathrm{M}$. The minimal inhibitory concentration (MIC) of the peptides was defined as the lowest concentration of peptide that inhibited growth by more than $90 \%$ after $48 \mathrm{~h}$ as compared to the control. Each fungal assay, by treatment and concentration, was performed in triplicate. MIC was calculated as the average of the three replications.

The in vitro minimal fungicidal concentration (MFC) was determined as described [26]. After $48 \mathrm{~h}$ of incubation, $20 \mu \mathrm{l}$ was subcultured from each well that showed no visible growth (growth inhibition of over 98\%), from the last positive well (growth similar to that for the growth control well), and from the growth control (extract-free medium) onto PDA plates. The plates were incubated at $24^{\circ} \mathrm{C}$ until growth was seen in the growth control subculture. The minimum fungicidal concentration was regarded as the lowest peptide concentration that did not yield any fungal growth on the solid medium. For each fungal isolate, treatment and concentration was tested in triplicate. MFC was calculated as the average of the three replications.

\section{In vivo antifungal activity assay}

The in vivo activity was assayed in fresh Valencia orange fruits (Citrus sinensis L. Osbeck), harvested two days before the experiment began. Fruits were surface disinfested with $200 \mathrm{ppm} \mathrm{NaOCl}$ solution for five minutes, rinsed three times in distilled water and then air dried on the bench. Next, fruits were injured with a sterile needle $(3 \mathrm{~mm}$ depth, 4 lesions per fruit along the equator) and inoculated with $5 \mu \mathrm{l}$ of an aqueous mixed suspension of the pathogen $P$. digitatum $\left(2 \times 10^{5}\right.$ conidia/ml) and the peptide at the desired concentration $(64,32$ or $6.4 \mu \mathrm{M})$. As negative and positive controls, water and Imazalil (1000 $\mathrm{ppm}$ of the active ingredient of the commercial fungicide Fungaflor 75 PS, Janssen Pharmaceutica) were used, respectively. Thioredoxin was not included as a third control since no antifungal activity was found in the in vitro experiment described above. After inoculation, fruits were kept at $20^{\circ} \mathrm{C}$ and $90 \%$ relative humidity for 7 days before evaluation. Fruits were scored according to the presence/absence of lesions. The probability of occurrence of healthy fruit was analyzed with a Binomial distribution and Logit link function, employing the GENMOD procedure of SAS Statistical Package (Statistical Analysis System, Version 9.2, 2008).

\section{Peptide stability}

All peptide stability assays were performed with the F. oxysporum f.sp. lycopersici strain, and the activity of the peptide was evaluated by the quantitative micro-spectrophotometric technique described above and using a peptide concentration of $4.0 \mu \mathrm{M}$, the MIC established in the in vitro antifungal activity assay. There was considered to be no activity when the absorbance was similar to the AbsW (with water and no peptide).

pH stability: The peptides were incubated at $37^{\circ} \mathrm{C}$ for $1 \mathrm{~h}$ in different buffer solutions, and then adjusted to $\mathrm{pH} 7$ before testing for antifungal activity. The solutions used at $100 \mathrm{mM}$ were: glycine/ $\mathrm{HCl}(\mathrm{pH} 3.0)$, acetate/acetic acid ( $\mathrm{pH}$ 5.), monobasic/dibasic sodium phosphate buffer ( $\mathrm{pH} 7.0$ ), Tris/ $\mathrm{HCl}$ ( $\mathrm{pH} 9.0)$, and monobasic/dibasic sodium phosphate ( $\mathrm{pH} 11.0)$.

Thermostability: Peptides were dissolved in PBS (pH 7.4) and incubated for $1 \mathrm{~h}$ at $0,60,80$ and $100^{\circ} \mathrm{C}$. The solutions were then cooled to $4^{\circ} \mathrm{C}$ and centrifuged $(15000 \times \mathrm{g} ; 10 \mathrm{~min})$ to remove any precipitation.

Protease digestion: The peptides were digested either with $1 \mathrm{mg} / \mathrm{ml}$ of pronase $\mathrm{E}$, proteinase $\mathrm{K}$ or trypsin. The reaction was performed at $37^{\circ} \mathrm{C}$ for the first two proteases and at $25^{\circ} \mathrm{C}$ for trypsin. The reaction was stopped by incubating first at $95^{\circ} \mathrm{C}$ for $5 \mathrm{~min}$ and then the mixture was cooled to $4^{\circ} \mathrm{C}$.

\section{Haemolytic activity}

Haemolytic activity for the two peptides (TrxAq-AMP and Pses3) was determined at different concentrations $(0.0,0.5,1.0,2.0,4.0$, 8.0, 16.0, 32.0, 64.0 and $128.0 \mu \mathrm{M}$ ) as described [27]. Briefly, $3 \mathrm{~mL}$ of fresh sheep blood cells were washed three times with $\mathrm{PBS}(\mathrm{pH} 7)$ then suspended in PBS $(10 \% \mathrm{v} / \mathrm{v})$. Blood cell suspension $(50 \mu \mathrm{L})$ was added to a peptide PBS suspension $(50 \mu \mathrm{l})$, mixed gently, incubated at $37^{\circ} \mathrm{C}$ for one hour and centrifuged $(2000 \times \mathrm{g} ; 5 \mathrm{~min})$. The supernatant was transferred to a 96-well microtiter plate and the absorbance of the sample (AbsS) measured at $450 \mathrm{~nm}$ (Multiscan FC, Thermoscientific, Shangai, China). As positive and negative controls, Triton $0.2 \% \mathrm{X}-100$ $(100 \%$ hemolysis $=\mathrm{AbsT})$ and PBS $(0 \%$ hemolysis $=\mathrm{AbsW})$ were used. Haemolysis \% (H\%) was determined as $\mathrm{H} \%=[(\mathrm{AbsS}-\mathrm{AbsW}) /(\mathrm{AbsT}$ $-\mathrm{AbsW})] \mathrm{x} 100$. 
Citation: Alem D, Díaz-Dellavalle P, Leoni C, De-Simone SG, Correa A, et al. (2014) In Search of Topical Agricultural Biofungicides: Properties of the Recombinant Antimicrobial Peptide TrxAq-AMP Obtained from Amaranthus quitensis. J Microb Biochem Technol 6: 268-273. doi:10.4172/1948-5948.1000155

\section{Results}

\section{Evaluation of different expression conditions and large scale purification of the recombinant protein Trx/His/Aq-AMP}

In order to obtain greater amounts of the recombinant protein $\operatorname{Tr} /$ His/Aq-AMP we evaluated different expression conditions including two E. coli strains (BL21(D3) pLys and Shuffle) and two different induction temperatures $\left(16^{\circ} \mathrm{C} \mathrm{ON}\right.$ and $37^{\circ} \mathrm{C}$ for $\left.4 \mathrm{~h}\right)$. The results showed better expression in the Shuffle strain with an induction temperature of $16^{\circ} \mathrm{C} \mathrm{ON}$ (data not shown). Next, we used these conditions for a large scale production and purification (1 l l) of Trx/His/Aq-AMP. Our results showed that the recombinant protein could be obtained at a final yield of $38 \mathrm{mg} / \mathrm{l}$ (Figure 1A and 1B). Following this we injected the recombinant protein into a Superdex 200 10/300 to determine its oligomeric state. The result indicated a molecular mass of around 500 $\mathrm{kDa}$, which corresponds to $20 \mathrm{Trx} / \mathrm{His} / \mathrm{Aq}$-AMP monomers (Figure 1C). This result was confirmed by dynamic light scattering (data not shown).

\section{In vitro fungal assays}

Both the synthetic and bacterially-expressed peptides presented antifungal activity against the four phytopathogens assayed. The thioredoxin alone did not display activity at the highest concentration of $128.0 \mu \mathrm{M}$ (Table 1). The MIC and MFC values against the four fungi for TrxAq-AMP were $4.0 \mu \mathrm{M}$ and $8.0 \mu \mathrm{M}$, respectively. Pses 3 presented a different response to each pathogen, with MIC values of $4.0 \mu \mathrm{M}$ for A. solani and F. oxysporum f. sp. lycopersici and $2.0 \mu \mathrm{M}$ for Penicillium sp., and MFC values of $8.0 \mu \mathrm{M}$ for A. solani and $4.0 \mu \mathrm{M}$ for the other three pathogens.

\section{In vivo fungal assay}

In the in vivo assay, only the peptide TrxAq-AMP at $64.0 \mu \mathrm{M}$ showed antifungal activity against $P$. digitatum controlling $62 \%$ of the lesions, which was lower than the positive control, the fungicide Imazalil $(84 \% ; \mathrm{p}<0.068)$. The peptide Pses 3 at $64.0 \mu \mathrm{M}$ only controlled $6 \%$ of the infection lesions, similar to the $3 \%$ observed for the negative control, water treatment $(\mathrm{p}<0.001)$ (Table 2 and Figure 2). No phytotoxic activity was observed at any dose of the assayed peptides.

\section{Peptide stability and haemolytic activity}

Stability differed between the synthetic peptide, Pses3, and the recombinant peptide TrxAq-AMP. TrxAq-AMP maintained its activity over a wide range of $\mathrm{pH}$ (from 3 to 11 ), temperatures $(0,60$, $80,100^{\circ} \mathrm{C}$ ) and even after exposure to proteases for $1 \mathrm{~h}$ and $16 \mathrm{~h}$. The
A

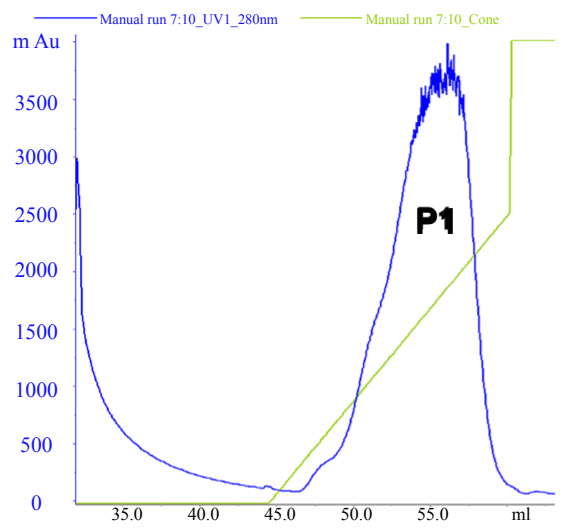

B

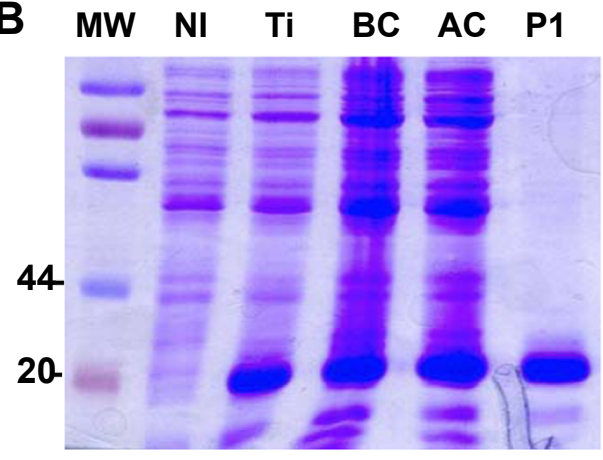

C

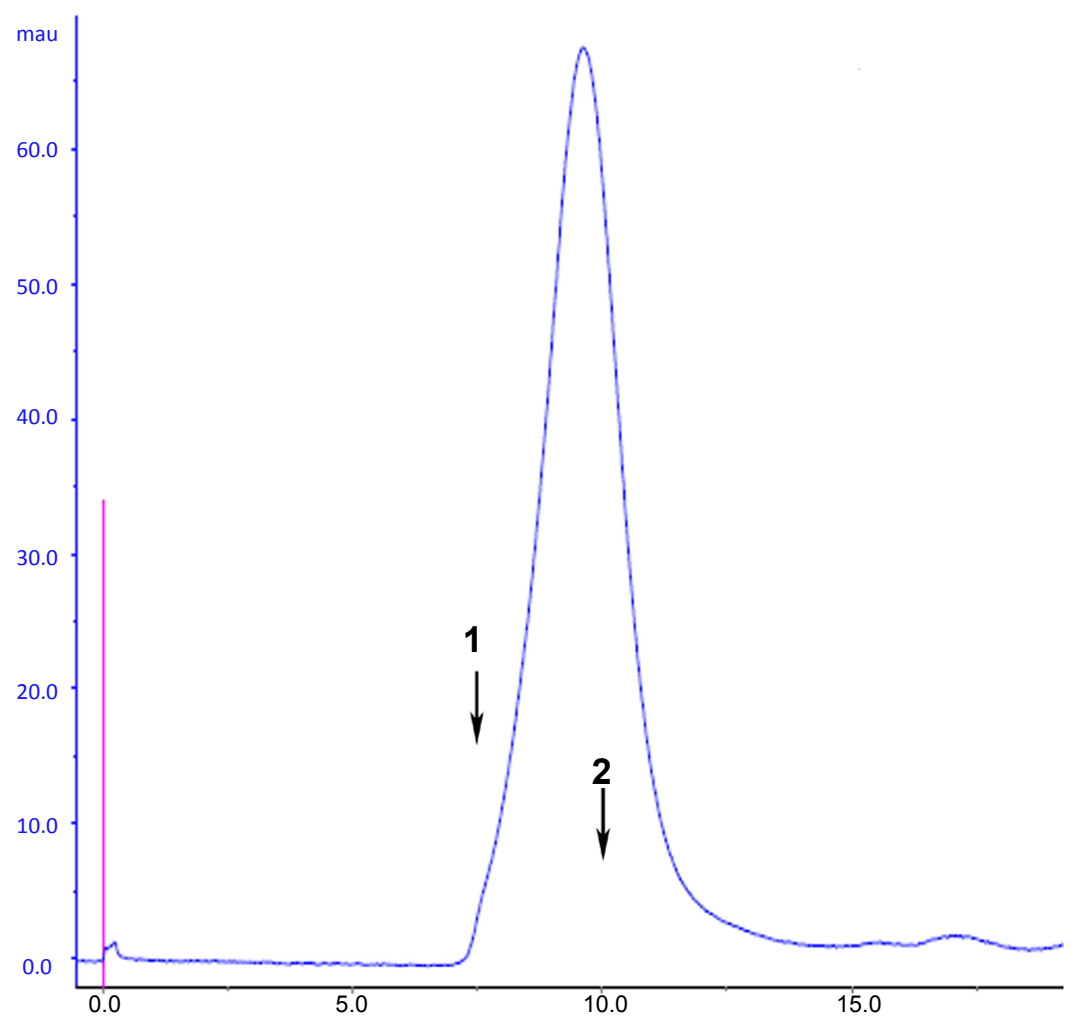

Figure 1: Purification and characterization of Trx/His/Aq-AMP. A. Chromatogram obtained from IMAC purification of Trx/His/Aq-AMP. B. SDS/PAGE 12\% of the purified protein. C. Size exclusion chromatography in a Superdex $20010 / 300$ of the P1 fraction. P1, eluted peak from IMAC purification. MW, molecular weight $(\mathrm{kDa}), \mathrm{NI}$, not induced; TI, total induced; BC, before column; AC; after column. Arrow 1 corresponds to the retention volume for Blue Dextran ( $>700 \mathrm{kDa})$; arrow 2 corresponds to the retention volume for Ferritin (440 kDa). 
Citation: Alem D, Díaz-Dellavalle P, Leoni C, De-Simone SG, Correa A, et al. (2014) In Search of Topical Agricultural Biofungicides: Properties of the Recombinant Antimicrobial Peptide TrxAq-AMP Obtained from Amaranthus quitensis. J Microb Biochem Technol 6: $268-273$. doi:10.4172/1948-5948.1000155

\begin{tabular}{|c|c|c|c|c|c|c|c|c|}
\hline & \multicolumn{2}{|c|}{ A. solani } & \multicolumn{2}{|c|}{$\begin{array}{c}\text { F. oxysporum f.sp. } \\
\text { lycopersici }\end{array}$} & \multicolumn{2}{|c|}{ P. digitatum } & \multicolumn{2}{|c|}{ P. Italicum } \\
\hline & MIC $^{a}$ & MFC $^{a}$ & MIC & MFC & MIC & MFC & MIC & MFC \\
\hline & $(\mu \mathrm{M})$ & $(\mu \mathrm{M})$ & $(\mu \mathrm{M})$ & $(\mu \mathrm{M})$ & $(\mu \mathrm{M})$ & $(\mu \mathrm{M})$ & $(\mu \mathrm{M})$ & $(\mu \mathrm{M})$ \\
\hline AqTrxAMP & 4 & 8 & 4 & 8 & 4 & 8 & 4 & 8 \\
\hline Pses3 & 4 & 8 & 4 & 4 & 2 & 4 & 2 & 4 \\
\hline Thioredoxin & $N D^{b}$ & ND & $>128$ & ND & $>128$ & ND & ND & ND \\
\hline
\end{tabular}

aMIC and MFC are the average of three replicates.

bND=not determined.

Table 1: Minimal inhibitory concentration (MIC) and minimal fungicidal concentration (MFC) of the peptides Pses3 and TrxAq-AMP for the phytopathogenic fung Alternaria solani, Fusarium oxysporum f.sp. Iycopersici, Penicillium digitatum y $P$. italicum.

\begin{tabular}{|c|c|c|c|c|c|}
\hline Treatment $^{\mathrm{a}}$ & $\begin{array}{l}\text { Estimated } \\
\text { mean }(\%)^{b}\end{array}$ & $\begin{array}{c}\text { Standard } \\
\text { Error }\end{array}$ & $\begin{array}{l}\text { Degrees of } \\
\text { Freedom }\end{array}$ & Pr>Chi-Sq & \\
\hline TrxAqAMP-6.4 $\mu \mathrm{M}$ & 0.095 & 0.27 & 1 & $<.0001$ & $\mathrm{a}^{\mathrm{c}}$ \\
\hline TrxAqAMP-32 $\mu \mathrm{M}$ & 0.177 & 0.339 & 1 & $<.0001$ & a \\
\hline TrxAqAMP-64 $\mu \mathrm{M}$ & 0.621 & 0.27 & 1 & 0.068 & $\mathrm{~b}$ \\
\hline Pses3-6.4 $\mu \mathrm{M}$ & 0 & 67881.74 & 1 & 0.999 & --- \\
\hline Pses3-32 $\mu \mathrm{M}$ & 0.031 & 0.723 & 1 & $<.0001$ & a \\
\hline Pses3-64 $\mu \mathrm{M}$ & 0.063 & 0.523 & 1 & $<.0001$ & $\mathrm{a}$ \\
\hline Control-Water & 0.031 & 0.723 & 1 & $<.0001$ & a \\
\hline Control-Imazalil 1000 ppm & 0.839 & 0.351 & 1 & $<.0001$ & c \\
\hline
\end{tabular}

a Valencia orange fruits were co-inoculated with a conidial suspension of $P$. digitatum $\left(2 \times 10^{5}\right.$ conidia $\left./ \mathrm{ml}\right)$ and either the peptide, the fungicide Imazalil or water ${ }^{\mathrm{b}}$ Means were estimated by the probability of occurrence of healthy fruits, analyzed with a Binomial distribution and Logit link function, employing the GENMOD procedure of SAS Statistical Package.

cTreatments statistically different are indicated with different letters.

Table 2: Estimated means for the percentage probability of occurrence of healthy fruits after co-inoculation with $P$. digitatum and the peptides TrxAq-AMP and Pses 3 .

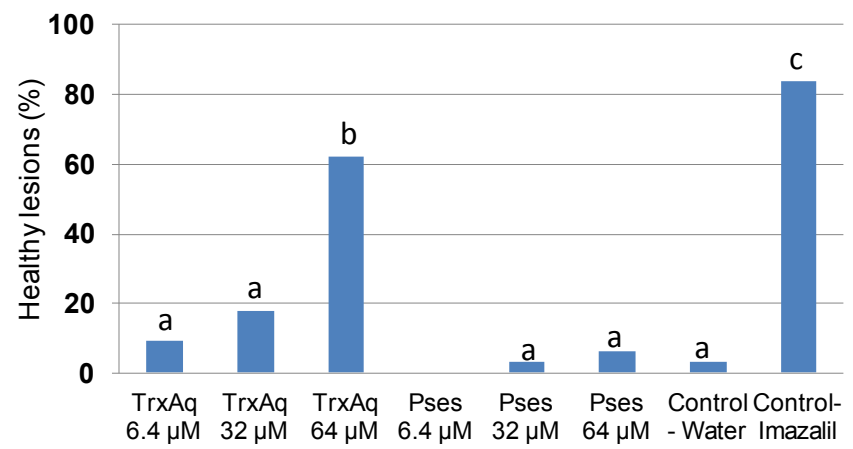

Figure 2: In vivo fungicidal activity of the peptides TrxAq-AMP and Pses3. The peptides were tested against Penicillium digitatum by evaluation of lesions formed on fresh Valencia oranges. Fruits were injured, inoculated with a mixed suspension of conidia $\left(2 \times 10^{5}\right.$ conidia/ml $)$ with peptide at various concentrations and incubated at $20^{\circ} \mathrm{C}$ for 7 days at $90 \%$ relative humidity.

synthetic peptide Pses 3 was sensitive to $\mathrm{pH}$, temperature and proteases. As expected, antifungal activity of both peptides was reduced in the presence of $\mathrm{CaCl}_{2}$ and $\mathrm{KCl}$ at $1.0 \mathrm{mM}$, and for TrxAq-AMP the activity was completely lost with $\mathrm{CaCl}_{2} 5.0 \mathrm{mM}$.

The synthetic peptide Pses 3 showed haemolytic activity with sheep blood cells at $32.0 \mu \mathrm{M}$, whereas TrxAq-AMP did not display any activity through to the highest concentration evaluated $(128.0 \mu \mathrm{M})$.

\section{Discussion}

Prokaryotic expression of cysteine-rich plant AMPs frequently presents difficulties, mainly due to the presence of disulfide bridges, ease of degradation and toxicity to the host. In this work, a naturally derived recombinant peptide was shown to have in vivo functional characteristics similar to those reported for another expression platform [28]. This work advances studies on AMP by evaluating both in vitro and in vivo activity for the same peptide generated by different means. One was synthesized and the other expressed in bacterial cells. While both peptides showed strong activity in vitro, only the naturally derived TrxAq-AMP had antifungal activity in vivo against $P$. digitatum. The best explanation is that stability was conferred by the presence of three disulfide bridges generated during expression in E. coli, which allows the peptide to overcome pathogen reaction and adverse environmental conditions [5]. AMPs are not always tested for both in vitro and in vivo activity, in spite of the relevance of in vivo effects for selecting promising AMP molecules for further development as new potential fungicides.

The lack of in vivo experiments can be attributed to the high cost of "classical technology" for large scale AMP production, either by synthetic procedures or through prokaryotic factory cells. Nevertheless more recent reports demonstrate the feasibility of obtaining functionally active peptides and proteins on a large scale by using plants as bioreactors [29-31]. There are several expression platforms of recombinant proteins in plants. When the performance of human serum albumin (HSA) obtained using different plant tissues is compared, production from seeds is the most convenient in terms of cost effectiveness [31,32].

The in vitro and in vivo activity suggests a high potential for TrxAqAMP as a bio-fungicide, as reported elsewhere for other peptidepathosystems [18]. Our peptide presented a dose-dependent response, where MIC and MFC could be established and therefore the dose for in vivo experiments could be defined. With an aqueous solution of TrxAq-AMP at $64 \mu \mathrm{M}$, we obtained $62 \%$ probability of healthy fruit against $P$. digitatum in fresh Valencia orange fruits, compared with $84 \%$ probability of healthy fruit with the commercial fungicide imazalil. Additionally, TrxAq-AMP was highly stable at different $\mathrm{pH}$ values's and temperatures, in a broader range than the conditions assayed with AcAMP2 [10]. In addition, TrxAq-AMP showed no haemolytic activity suggesting a high degree of safety. This last property of TrxAq-AMP is a significant advantage compared to the linear peptide Pses3, which was highly haemolytic suggesting a potential health risk. These results indicate TrxAq-AMP may be a promising alternative to conventional fungicides. Conventional fungicides give rise to concern due to the development of fungal resistance and their negative side effects on human health and the environment. In particular, the citrus industry is threatened by difficulties in controlling post-harvest decay [4].

The sequence of the molecule from A. quitensis seeds (Aq-AMP2) is identical to that reported for A. caudatus (Ac-AMP2) [10,13]. After demonstrating the potential of TrxAq-AMP as a novel class of biofungicides, the challenge is to go further in scaling up expression for mass production. Based on actual knowledge, the most promising path is the use of eukaryotic platforms. With these platforms, both technological adjustments and economic trade-offs should be considered.

Topical application of naturally derived AMPs for controlling pathogens is under development. Our group is focusing on phytopathogens of agricultural relevance, mainly postharvest pathogens and pathogens affecting fruits for fresh consumption. To be considered as a potential biopesticide, AMPs should combine certain intrinsic properties such as no haemolytic activity, and stability after exposure to proteases as well as to a range of $\mathrm{pH}$ and temperatures. 
Citation: Alem D, Díaz-Dellavalle P, Leoni C, De-Simone SG, Correa A, et al. (2014) In Search of Topical Agricultural Biofungicides: Properties of the Recombinant Antimicrobial Peptide TrxAq-AMP Obtained from Amaranthus quitensis. J Microb Biochem Technol 6: 268-273. doi:10.4172/1948-5948.1000155

Also, other desired properties are high specificity for target pathogens, effective at low dosages, biodegradability and low risk for resistance development by the pathogen population.

Our next step is to scale-up Aq-AMP production, and for this we are evaluating prokaryotic and eukaryotic platforms. The ideal platform should consider the natural conformation of the peptide to assure its functional activity, have a low risk for cross contamination, produce significant amounts of the peptide and the peptide should be easily extracted in standard solvents. Finally, production costs should be low enough to allow for further development of a commercial product. Prokaryotic platforms have several advantages; however we are opting for eukaryotic ones and more specifically for transgenic plants as biofactories. Concomitantly, more studies simulating the environment of AMP application are needed, as well as a new strategy for AMP application, since these biomolecules behave differently than classical synthetic pesticides.

\section{Acknowledgements}

This research was funded by the National Institute of Agricultural Research (INIA) and the National Agency of Research and Innovation (ANII) of Uruguay. We also acknowledge the Phytopathology and Post-harvest team at INIA Salto Grande Research Station for their assistance with the fruit decay experiment, Gabriel Ciappesoni for his assistance with statistical analysis and Sara Murchio for her assistance with the in vitro experiments.

\section{References}

1. Broekaert W, Cammue B, De Bolle M, Thevissen K, De Samblanx G, et al. (1997) Antimicrobial peptides from plant. Critical Reviews in Plant Science 16: 297-323

2. de Souza Cândido E, e Silva Cardoso MH, Sousa DA, Viana JC, de OliveiraJúnior NG, et al. (2014) The use of versatile plant antimicrobial peptides in agribusiness and human health. Peptides 55: 65-78.

3. Lay FT, Anderson MA (2005) Defensins--components of the innate immune system in plants. Curr Protein Pept Sci 6: 85-101.

4. Palou L,Smilanick J, Droby S (2008) Alternatives to conventional fungicides for the control of citrus postharvest green and blue moulds. Stewart Postharvest Review 2: 1-16.

5. López-García B, San Segundo B, Coca M (2012) Antimicrobial peptides as a promising alternative for plant disease protection. In: Rajasekaran, K Cary, J.W., Jaynes, J.M., Montesinos, E. ( eds.). Small Wonders: Peptides for disease control. American Chemical Society: Washington, DC, 2012. p. $263-$ 294. (ACS Symposium Series; 1095)

6. Janisiewicz W, Pereira I, Almeida M, Roberts D, Wisniewski M, Kurtenbach E (2008) Improved biocontrol of fruit decay fungi with Pichia pastoris recombinant strains expressing Psd1 antifungal peptide. Postharvest Biology and Technology 47: 218-225.

7. Jones RW, Prusky D (2002) Expression of an Antifungal Peptide in Saccharomyces: A New Approach for Biological Control of the Postharvest Disease Caused by Colletotrichum coccodes. Phytopathology 92: 33-37.

8. Lacerda AF, Vasconcelos EA2, Pelegrini PB3, Grossi de Sa MF2 (2014) Antifungal defensins and their role in plant defense. Front Microbiol 5: 116

9. Souza AL, Díaz-Dellavalle $P$, Cabrera $A$, Larrañaga $P$, Dalla-Rizza $M$, et al (2013) Antimicrobial activity of pleurocidin is retained in Plc-2, a C-terminal 12-amino acid fragment. Peptides 45: 78-84

10. Broekaert WF, Marien W, Terras FR, De Bolle MF, Proost P, et al. (1992) Antimicrobial peptides from Amaranthus caudatus seeds with sequence homology to the cysteine glycine-rich domain of chitin-binding proteins. Biochemistry 31: 4308-4314

11. Lipkin A, Anisimova V, Nikonorova A, Babakov A, Krause E, et al. (2005) An antimicrobial peptide Ar-AMP from amaranth (Amaranthus retroflexus L.) seeds. Phytochemistry 66: 2426-2431.

12. Rivillas-Acevedo LA, Soriano-García M (2007) Isolation and biochemical characterization of an antifungal peptide from Amaranthus hypochondriacus seeds. J Agric Food Chem 55: 10156-10161.
13. Díaz Dellavalle P (2013) Búsqueda, aislamiento, caracterización estructural y funcional de péptidos antifúngicos. Tesis de Doctorado, Facultad de Química Universidad de la República, Montevideo, 217 p.

14. Bommarius B, Jenssen H, Elliott M, Kindrachuk J, Pasupuleti M, et al. (2010) Cost-effective expression and purification of antimicrobial and host defense peptides in Escherichia coli. Peptides 31: 1957-1965.

15. Capparelli R, Palumbo D, lannaccone M, Ventimiglia I, Di Salle E, et al. (2006) Cloning and expression of two plant proteins: similar antimicrobial activity of native and recombinant form. Biotechnol Lett 28: 943-949.

16. Kovalskaya N, Hammond RW (2009) Expression and functional characterization of the plant antimicrobial snakin-1 and defensin recombinant proteins. Protein Expr Purif 63: 12-17.

17. Li Y, Li X, Wang G (2006) Cloning, expression, isotope labeling, and purification of human antimicrobial peptide LL-37 in Escherichia coli for NMR studies. Protein Expr Purif 47: 498-505.

18. Wu Y, He Y, Ge X (2011) Functional characterization of the recombinan antimicrobial peptide Trx-Ace-AMP1 and its application on the control of tomato early blight disease. Appl Microbiol Biotechnol 90: 1303-1310.

19. Company N, Nadal A, La Paz JL, Martínez S, Rasche S, et al. (2014) The production of recombinant cationic a-helical antimicrobial peptides in plant cells induces the formation of protein bodies derived from the endoplasmic reticulum. Plant Biotechnology Journal 12: 81-92.

20. Lico C, Santi L, Twyman RM, Pezzotti M, Avesani L (2012) The use of plants for the production of therapeutic human peptides. Plant Cell Rep 31: 439-451.

21. Morassutti C, De Amicis F, Skerlavaj B, Zanetti M, Marchetti S (2002) Production of a recombinant antimicrobial peptide in transgenic plants using a modified VMA intein expression system. FEBS Lett 519: 141-146.

22. Swathi Anuradha T, Divya K, Jami SK, Kirti PB (2008) Transgenic tobacco and peanut plants expressing a mustard defensin show resistance to fungal pathogens. Plant Cell Rep 27: 1777-1786.

23. De Bolle MF, David KM, Rees SB, Vanderleyden J, Cammue BP, et al. (1993) Cloning and characterization of a cDNA encoding an antimicrobial chitin-binding protein from amaranth, Amaranthus caudatus. Plant Mol Biol 22: 1187-1190.

24. Schägger H (2006) Tricine-SDS-PAGE. Nat Protoc 1: 16-22.

25. Broekaert WF, Terras FR, Cammue BP, Vanderleyden J (1990) An automated quantitative assay for fungal growth-inhibition. FEMS Microbiol. Lett. 69: 55-59

26. Díaz Dellavalle P, Cabrera A, Alem D, Larrañaga P, Ferreira F, et al. (2011) Antifungal activity of medicinal plant extracts against phytopathogenic fungus Alternaria spp. Chilean Journal of Agricultural Research 71: 231-239.

27. Cornut I, Büttner K, Dasseux JL, Dufourcq J (1994) The amphipathic alphahelix concept. Application to the de novo design of ideally amphipathic Leu, Lys peptides with hemolytic activity higher than that of melittin. FEBS Lett 349 : $29-33$.

28. De Bolle MF, Osborn RW, Goderis IJ, Noe L, Acland D, et al. (1996) Antimicrobial peptides from Mirabilis jalapa and Amaranthus caudatus: expression, processing, localization and biological activity in transgenic tobacco. Plant Molecular Biology 31: 993-1008.

29. Stoger E, Ma JK, Fischer R, Christou P (2005) Sowing the seeds of success: pharmaceutical proteins from plants. Curr Opin Biotechnol 16: 167-173.

30. Takaiwa F, Hirose S, Takagi H, Yang L, Wakasa Y (2009) Deposition of a recombinant peptide in ER-derived protein bodies by retention with cysteinerich prolamins in transgenic rice seed. Planta 229: 1147-1158.

31. He Y, Ning T, Xie T, Qiu Q, Zhang L, et al. (2011) Large-scale production of functional human serum albumin from transgenic rice seeds. Proc Natl Acad Sci U S A 108: 19078-19083.

32. Boothe J, Nykiforuk C, Shen Y, Zaplachinski S, Szarka S, et al. (2010) Seed based expression systems for plant molecular farming. Plant Biotechnol J 8 : 588-606. 